\title{
Crossing Boundaries: "Some College" and the Role of Schools in Educational Assortative Mating
}

\author{
David McClendon \\ Pew Research Center \\ 1615 L Street NW \#800, Washington, DC 20036 \\ david.m.mcclendon@gmail.com
}

\begin{abstract}
As more Americans delay marriage and meet romantic partners online, schools may be becoming less important for educational assortative mating. However, although fewer people meet their spouse as students, social ties formed during college may continue to shape partner choice later in adulthood. Here I focus on young adults with "some college, no degree" to see what, if any, marriage-market benefit is gained from exposure to highly-educated social networks in college. Using data from NLSY-1997, including newly collected postsecondary transcripts, I find young adults with "some college" are more likely than their less educated peers to marry a college graduate, especially if they attended a 4-year school. But young adults with bachelor's degrees still hold an advantage, even after controlling for duration of schooling. The results support the role of schools in shaping opportunities to meet partners but highlight the value of a college degree on the marriage market.
\end{abstract}

ACKNOWLEDGEMENTS

This research benefitted from grants from the Eunice Kennedy Shriver National Institute of Child Health and Human Development: Education in the Transition to Adulthood (R01 HD061551, Chandra Muller), Population Research Center (R24 HD042849, Mark Hayward), and Training Program in Population Studies (T32HD007081, Kelly Raley) to the Population Research Center at The University of Texas at Austin, as well as support from the Pew Charitable Trusts and the John Templeton Foundation. I am grateful for helpful comments and suggestions from Kelly Raley, my mentors and fellow graduate students at University of Texas at Austin, the Diversity across the Life Course group at the University of Texas at Austin, and my colleagues at the Pew Research Center. I am solely responsible for any opinions or errors in the analysis. 
In his classic time-gap hypothesis of educational assortative mating, Robert Mare (1991) posited that trends in educational homogamy are shaped by the timing of marriage relative to school completion. According to this theory, educational homogamy should be more common when marriage occurs soon after young adults graduate because schools act as important marriage markets. As marriage is delayed to later ages, beyond when most people have finished schooling, the time-gap hypothesis anticipates that educational homogamy will decrease because young adults will choose partners from more educationally diverse settings. However, while trends in educational homogamy from 1940-1980 support the time-gap hypothesis, more recent trends do not: educational homogamy remains strong and pervasive even as average ages at first marriage for men and women have risen to 29 and 27 (Census, 2011; Rosenfeld, 2008; Schwartz, 2013). In fact, today's college-educated adults are less likely to cross educational boundaries when choosing a spouse than in previous eras (Schwartz \& Mare, 2005).

On the one hand, these trends could indicate that partner preferences have become more important than schools for sorting partners. The disappearance of middle-income, low-skilled jobs and the polarization of the labor market have made a college degree more critical for earnings and job security, which has increased the value of a college degree on the marriage market (Autor \& Dorn, 2013; Fernández, Guner, \& Knowles, 2005; Schwartz, 2013). Online dating has also removed many of the traditional social barriers to meeting partners, potentially allowing preferences to play a more explicit role in partner selection (Rosenfeld \& Thomas, 2012).

On the other hand, opportunities to meet may still matter for educational assortative mating, but the role of schools may have changed. Mare's original time-gap hypothesis assumed that schools functioned as local dating markets where young adults met their spouse (Kalmijn \& 
Flap, 2001). However, schools also provide opportunities to form long-lasting friendships and broader social networks (Feld, 1981). Thus, even if most men and women do not meet their future spouse while enrolled in school, they will likely still draw on social ties formed through school to find a spouse later in adulthood, aided by social media sites like Facebook (Arum, Roksa, \& Budig, 2008; Laumann, Ellingson, Mahay, Paik, \& Youm, 2004).

In this paper, I focus on heterogeneity in postsecondary education to better understand the role that schools play in structuring opportunities to meet partners in the years following school completion. Despite increased enrollment in higher education, some $44 \%$ of U.S. young adults at 4-year institutions and 70\% at 2-year institutions do not complete their degrees within six years (Symonds \& Schwartz, 2011). These young adults with "some college" bear many of the financial costs associated with higher education but do not enjoy the economic or health benefits of a degree (Hout, 2012; Zajacova, Rogers, \& Johnson-Lawrence, 2012). Given that a degree is valued not only by employers but also by potential mates, young adults with some college could face a similar penalty on the marriage market. Yet, if schools offer opportunities to meet collegeeducated partners, and not just credentials to satisfy marriage-market demands, young adults with some college should see some benefit to attendance (relative to their peers with no college experience) and be more likely to marry a spouse with a college degree.

I draw on data from rounds 1-15 of the National Longitudinal Study of Young 1997 (NLSY97) to analyze the association between exposure to postsecondary education (enrollment, school type, and credits earned), degree attainment, and spouse's education among married respondents. I also use newly collected college transcript data on the NLSY97 cohort for more accurate education measures. In addition, I control for factors that select people into college and are associated with marriage (family background and high school performance), as well as 
mediating factors like employment, earnings, and occupational status that are influenced by college attendance and completion but also improve marriage prospects.

\section{BACKGROUND}

\section{Education and Opportunities to Meet}

Supply-side theories of educational assortative mating argue that schools are an important social intermediary in the marriage market (Kalmijn \& Flap, 2001; Kalmijn, 1998; Mare, 1991). Like religious congregations and workplaces, schools are key social settings where adolescents and young adults meet and interact with peers and form long-lasting friendships (Frank, Muller, \& Mueller, 2013; McPherson, Smith-lovin, \& Cook, 2001). Given later ages at marriage and social norms against marriage before school completion (Census, 2011; Thornton, Axinn, \& Teachman, 1995), the friends and contacts that men and women make during school, especially if they attend college, are likely to be considered as potential marriage partners. Many young adults also rely on the networks they formed at school as they search for partners later in adulthood (Arum et al., 2008), a dynamic made even easier with social media sites that allow school friends to keep in touch long after graduation (Laumann et al., 2004).

As Mare and others have argued, the hierarchical structure of the education system in the United States means that schools not only help people locate partners, but they also promote educational homogamy, especially among the college-educated (Blossfeld, 2009). As young adults finish high school and consider higher education, many choose to enter the workforce rather than attend college. Among those who continue their education, some attend two-year institutions to earn associates or vocational degrees, while others attend four-year institutions for bachelor's degrees. An even smaller share pursues master's, professional, or other advanced degrees. Along the way, this filtering process— "structural homogenization"—-makes networks 
and contacts, and the pool of partners, homogenous with respect to education at each level of attainment (Blau, 1994). In this way, schools facilitate educational homogamy by structuring opportunities to meet educationally similar partners, both during school and after graduation.

\section{Education and Partner Preferences}

By contrast, demand-side theories of educational assortative mating expect that educational homogamy has more to do with people's preferences for partners than opportunities to meet. In the United States, most men and women report that they would like to marry someone who has similar or more education than themselves (Buss, Shackelford, Kirkpatrick, \& Larsen, 2001; Raley \& Bratter, 2004; South, 1991). One reason is that education signals a person's long-term economic prospects (Sweeney \& Cancian, 2004; Sweeney, 2002; Xie, Raymo, Goyette, \& Thornton, 2003). In today's highly polarized, knowledge-based labor market, young adults with college degrees have better job prospects and earn more money, on average, than those without degrees (Autor \& Dorn, 2013; Hout, 2012). Socioeconomic status is also uncertain early in adulthood, so educational credentials often provide a useful proxy for a potential partner's future economic status and lifestyle (Oppenheimer, 1988). In addition, education is closely connected to social class. Rather than merely signal economic prospects, education may act as a proxy for cultural compatibility between partners related to values, tastes, and overall lifestyle, as well as family background (DiMaggio \& Mohr, 1985; Press, 2004; Swidler, 2001).

Partner preferences are consequential for assortative mating because marriage requires mutual attraction. If everyone in the marriage market has vertical preferences for partner's education - that is, if they prefer a similar or more highly educated spouse, and avoid partners with less education — competition for highly educated partners will engender educational homogamy because most people will only be able to strike a marriage bargain with people of a 
similar education level. College-educated young adults, reluctant to marry down, will match with each other, while the less educated will be left unable to compete, forced to either forego marriage or settle for a partner with similar education. This suggests that merely having opportunities to meet college-educated partners through school may not be enough-a degree may also be required to marry a college-educated partner. In other words, contemporary patterns of educational homogamy may simply reflect people's individual preferences and have little to do with schools structuring partner choice.

\section{Current Study}

Diversity in postsecondary educational experiences offers a unique vantage point from which to understand the roles of schools and preferences in sorting partners on educational attainment. Although rates of college attendance have increased dramatically since the middle of the twentieth century, a growing share of young adults has some college experience but has not earned a degree (Symonds \& Schwartz, 2011). In fact, in the full sample of NLSY-97 respondents, "some college, no degree" is the modal category of educational attainment.

On the one hand, compared to men and women with no college experience, young adults with "some college" are exposed to the college environment and have had greater opportunities to make friends and meet potential partners with college degrees. Even though many men and women in the "some college" group may not live on campus—which, presumably, facilitates stronger, more intimate social ties - they do work side by side with college-educated peers in the classroom and in groups and organizations central to campus life. If schools act as social intermediaries in the marriage market and structure opportunities to meet partners, young adults should see some benefit to college attendance, even if they do not earn a degree, relative to their peers with only high school degrees. Holding all else equal (e.g., family background, skills, and 
employment and income), men and women with some college should be more likely to marry a college-educated spouse compared with high school educated adults with no college experience.

At the same time, young adults with some college still lack the educational credentials and many of the associated characteristics — higher level of socioeconomic status, better healththat college graduates, on average, are looking for in potential partners. Compared to their peers with college degrees, young adults with some college, on average, earn less money and have more uncertain long-term job prospects (Hout, 2012). In addition, many are burdened with student debts that make them less attractive to potential partners and feel less ready for marriage (Addo, 2014; Bozick \& Estacion, 2014). If partner preferences are strong enough—that is, if college graduates use educational credentials as a primary filter to accept and reject potential partners-young adults with some college may be overlooked by college graduates on the marriage market, even though they are imbedded in the same social networks from school.

In this study, I focus on older young adults (ages 24-31) for two reasons. First, these are ages when most young adults, especially the college-educated, are seriously considering marriage. Although non-school environments like work and occupations are beginning to influence social networks and opportunities to meet partners at these ages (McClendon, Kuo, \& Raley, 2014), school continues to be a significant source of social ties. Second, focusing on older young adults avoids conflating two different kinds of young adults with "some college": those who marry prior to school completion and those who search for partners after dropping out of school. The former are more likely to be evaluated by potential partners as "college-educated," even if they do not end up graduating after marriage. In contrast, the latter group is evaluated by potential partners as having "some college, no degree" and, thus, provides a clearer test of partner preferences vs. opportunities to meet. 
Postsecondary education is also associated with other characteristics that influence marriage prospects but are incidental to opportunities to meet. Although young adults with some college fare worse on the job market compared to those who hold bachelor's degrees, they still do better than their peers with no college experience. One reason may be that postsecondary education, even if it does not lead to a degree, improves a person's human capital. While a degree is a more efficient way to signal one's stock of skills and capacities to employers, young adults with some college may still learn and acquire training through postsecondary schooling that make them more attractive job candidates compared to young adults with only a high school degree. As a result, having some college experience may lead to better career opportunities and higher earnings, which would improve a person's position in the marriage market. I account for these mediating factors by controlling for employment status, earnings, and occupational education (share of occupational peers with a college degree).

College attendance and completion also reflect skills and capacities acquired prior to postsecondary education, as well as social class background - factors that may confound the association between education and marriage. On the one hand, young adults with some college may have better prospects on the marriage market, relative to their less educated peers, because they are smarter and more capable partners and/or because they come from more advantaged backgrounds. On the other hand, prior skills and social class are also predictive of college completion. Despite having greater access to college-educated partners, young adults with some college might be less attractive than degree holders because they come from lower class backgrounds or because they do not have the same skills or smarts as those with degrees (Musick, Brand, \& Davis, 2012). For these reasons, I control for young adults' prior skills and 
performance in high school (course-taking, GPA, and test scores) and their social class background (parent's education and family income).

Based on the above discussion, I make the following hypotheses about the association between educational attainment, postsecondary experience, and mate selection. If schools matter for sorting partners:

Hypothesis 1: Young adults with "some college, no degree" should be more likely to marry a college graduate (vs. a non-college graduate) compared with young adults who have no college experience.

Furthermore, because there should be more opportunities to meet college graduates at schools that grant bachelor's degrees rather than only associate's degrees, I expect to see variation in marriage-market outcomes based on the type of institution.

Hypothesis 2: Young adults with "some college, no degree" who attend a 4-year college should be more likely than those who attended only a 2-year college to marry a college graduate.

I also expect variation within the some-college group based on duration of exposure to the college environment. For instance, young adults who attend college for only a semester should have weaker ties and fewer opportunities to form relationships with college-educated partners, in the long run, compared to those who attend school for three years-even if both groups do not end up earning degrees. Again, the effect of duration on assortative mating should depend on the type of institution.

Hypothesis 3: Duration of college attendance should be positively associated with marriage to a college graduate. 
Finally, we might expect the effect of college attendance on spouse's education to vary by gender. In surveys, men report a greater willingness to marry down in education than women (Raley \& Bratter, 2004; South, 1991). This suggests that women should benefit more from opportunities to meet college-educated male partners. While college-educated women may reject men with only "some college," college-educated men may be more willing to marry a woman they know through school but who does not have a degree.

Hypothesis 4: College attendance should be more strongly associated with partner choice for women than men.

\section{METHOdS}

Data

Data for the analysis come from Rounds 1-15 of the 1997 National Longitudinal Survey of Youth (NLSY97), a national sample survey of 8,984 youth, born between January 1980 and December 1984. Respondents have been surveyed annually since 1997 and asked, among other topics, about their family formation histories and spouse's social characteristics. With the use of the sampling weights provided, the NLSY97 is designed to be nationally representative. I used sampling weights from the first round for all analyses.

I focus on the subset of NLSY97 respondents who married after age 24 by round 15 of data collection. Respondents who had missing data on the date of first marriage $(\mathrm{N}=66)$, whose last interview as of round 15 was prior to age $18(\mathrm{~N}=144)$, or who married prior to age 24 $(\mathrm{N}=1,804)$ were excluded from the sample. I also excluded married respondents who had missing data on spouse's educational attainment $(\mathrm{N}=50)$. In addition, I dropped young adults who did not complete high school (or who married prior to finishing high school) because they were not 
eligible to enroll in postsecondary education and because there were very few marriages between members of this group and college-educated spouses. This left a sample of 1,469 married respondents (739 men and 730 women).

\section{Measures}

\section{Dependent Variable}

The dependent variable was a dichotomous variable that distinguishes between marriage to a spouse with a bachelor's degree $(=1)$ and marriage to a spouse without a bachelor's degree $(=0)$. NLSY97 respondents were asked at each survey round about their own level of educational attainment as well as that of their spouse, even in the rare cases when their spouse did not currently reside in the household. To ensure that spouse's education was measured at the time of marriage, I used the closest survey round to the date of first marriage. Respondents were not asked whether their spouse had some college experience but no degree, only highest degree earned. Among respondents who married for the first time after age 24, 592 married a spouse with a bachelor's degree (319 men and 273 women) and 877 married a spouse with less than a bachelor's degree (420 men and 457 women).

\section{[TABLE 1 ABOUT HERE]}

\section{Respondent Characteristics}

I relied on two data sources to create educational attainment and postsecondary schooling measures: self-reports by respondents and newly collected college transcripts. Transcript data have the advantage of providing more accurate measures of degree attainment and number of credits, which can be prone to error and non-reporting bias in surveys of respondents. However, a major drawback of the NLSY transcripts is incomplete data: in some cases, respondents did not sign waivers to allow NLSY to collect transcripts, while, in other cases, schools did not respond 
to requests for transcripts. In all, NLSY was able to collect transcripts and/or verified enrollment for $70 \%$ of the 5,500 NLSY participants who reported attending some postsecondary education.

All educational attainment variables were measured at the June of the year of first marriage. This helps account for the fact that many young adults marry in anticipation of graduation or shortly following graduation. For example, respondents who married in March of a given year were given the level of educational attainment they earned in the June of that year.

Educational attainment was measured in three different ways to test each hypothesis. First, I created a measure of degree attainment that included "some college, no degree" respondents who reported attending or earned post-secondary credits but did not complete their degree - as a separate category. This provided a basic test of how young adults with some postsecondary education, but only a high school degree, fared on the marriage market relative to their less-educated and more-educated peers (Hypothesis 1). Second, to test the effect of school type (Hypothesis 2), I split the "some college" group into those who only attended a 2-year institution and those who attended a 4-year institution. Third, to test the effect of amount of exposure to postsecondary schooling (Hypothesis 3), I created two continuous, time-varying variables of the cumulative number of credits earned at 2-year and 4-year institutions. Number of credits captures both duration (e.g. time enrolled) as well as intensity (time spent in the classroom) of exposure to opportunities to meet partners through school. The survey data provided additional measures that were not available in the transcript data, e.g., number of months enrolled in school and number of courses taken, but these measures behaved similarly to number of credits earned in ancillary analyses.

Columns 1 and 2 in Table 2 compare educational attainment and mean number of credits as measured in the survey and transcript data for the analytic sample, measured in the June of the 
year of first marriage (results are similar for full sample of young adults). Surprisingly, differences in the educational distribution between survey and transcript measures are small. Slightly smaller shares of married respondents hold bachelor's degrees in the transcript data compared to the survey. More surprising is that the mean number of 2-year and 4-year credits is similar across data sources. This is notable because the survey measure is designed to capture credits earned toward a 2-year or 4-year degree while the transcript measure reflects the total number of credits earned at each institution, regardless of whether they were earned toward a degree. The correlation between survey and transcript measures of 4-year credits is quite high ( $\mathrm{r}$ $=0.73)$ and more modest for 2 -year credits $(\mathrm{r}=0.57)$.

\section{[TABLE 2 ABOUT HERE]}

To account for potential differences in measurement of education across data sources, I first ran all models using the survey measures (full survey sample), the transcript measures (restricted to non-missing transcript respondents), and the survey measures using the restricted transcript sample. In all three cases, the associations between educational measures and partner's education were substantively similar. Given that the transcript data are more reliable than survey reports, I opted for a multiple imputation approach. I used transcript measures of educational attainment and number of credits when available and imputed missing values using respondents' survey reports of attainment and credits as predictors (along with other key demographic characteristics). The third column in Table 2 shows educational attainment and number of credits for men and women from this approach.

I also controlled for a set of covariates associated with educational attainment, college exposure, and partner selection. I controlled for time-varying indicators of socioeconomic status, including whether respondents are currently enrolled in school (yes/no), annual earnings 
(logged), employment status (not employed, working part-time, and working full-time), and occupational education. Occupational education is measured as the percentage of adults ages 2529 in a given occupation with a college degree in the 2000 census. Values range from 0 to 1. Occupational education captures aspects of occupational status as well as opportunities to meet college-educated partners through work (McClendon et al., 2014). Because respondents who were not employed do not have valid values on occupational education, I centered this measure on the sample mean for the employed and assigned zeros (the mean value) for those not employed in a given year.

I controlled for social class background using parent's highest degree earned and total family income measured at round 1 of the survey. To control for pre-college performance and skills that could influence college attendance, completion, and spouse's education, I used measures of high school GPA, ASVAB score, and a dichotomous indicator of advanced math course-taking. Finally, I controlled for a standard set of demographic variables: age, raceethnicity, family structure at age 12, first birth status, religious affiliation, region and urban residence.

\section{[TABLE 3 ABOUT HERE]}

To correct for potential bias in the estimates resulting from the exclusion of respondents who married prior to age 24 , all analyses were corrected for sample selection using the two-stage procedure described by Heckman (1979). First, a probit model was constructed to predict selection into the sample using all time-invariant characteristics. A hazard rate for exclusion from the sample was then constructed based on the predicted values from this model (Berk, 1983). The hazard rate was then entered as a control into the equations predicting spouse's education. 
I handled missing data using the Chained equations in MI command in Stata 13 (White, Royston, \& Wood, 2011). I generated five imputed data sets to impute missing data on all categorical and continuous independent variables included in the analysis, including educational measures (described above). Five imputations are considered sufficient to make good inferences and to get parameter estimates that are close to being fully efficient (Allison, 2009). Results were substantively equivalent before and after multiple imputation. I present results from models using the multiple imputed data.

\section{Analytic Approach}

I start by examining the educational gradient in spouse's education (college-educated vs. noncollege educated spouse) without controls, treating "some college" as its own category. After establishing a baseline for how young adults with some college fare relative to their peers, I move to the multivariate analysis. I estimate logistic regression models of spouse's education among married respondents, predicting marriage to a college-educated spouse (bachelor's or more) vs. a non-college educated spouse. The first model treats "some college" as a distinct educational category to see whether having some postsecondary education, but only a high school degree, improves young adults' chances of marrying a college graduate compared to young adults without postsecondary experience (Hypothesis 1). Model 2 tests the second hypothesis that access to college-educated spouses depends on the type of institution. I distinguish between those with only 2-year college experience and those with some 4-year college experience. Model 3 includes the number of college credits (by school type) to test the third hypothesis about the relationship between amount of exposure to college (opportunities to meet) and marriage to a college-educated spouse. In all models, I control for respondent's demographic characteristics, family background, high school performance, and socioeconomic 
status indicators. I test for gender differences in the effects of schooling on partner selection (Hypothesis 4) by pooling men and women together and included an interaction term between gender and education (attainment categories and number of credits).

\section{RESULTS}

Table 4 shows the share of respondents in the sample who married a college-educated spouse (bachelor's degree or more) by respondents' level of education. Overall, there was a clear educational gradient among respondents in spouse's education. As expected, given current levels of educational homogamy in the general population, young adults with bachelor's degrees were the group most likely to marry a college-educated spouse (68\% did so). Around half (49\%) of associate's degree holders married a college-educated spouse, while young adults with only a high school degree, and no postsecondary education, were the group least likely to marry a college graduate (13\%). Young adults with some college, but no degree, fell in the middle of the spectrum. Consistent with Hypothesis 1, 29\% of young adults in the sample with some college married a college graduate - twice the share among those with only a high school degree, but a smaller share than among associate's degree holders. Moreover, consistent with Hypothesis 2, there was important variation in the some college group based on the type of institution attended: young adults with 4-year college experience were significantly more likely to marry a collegeeducated spouse than those who only attended a 2-year institution.

\section{[TABLE 4 ABOUT HERE]}

Table 5 presents results from logistic regression models predicting spouse's education (college graduate vs. not) with respondent's educational attainment, controlling for a host of socioeconomic indicators and background characteristics. Model 1 tests the first hypothesis and 
treats young adults with some college, no degree as a single group. In support of Hypothesis 1, young adults with some college had significantly greater odds - more than 2 to 1 odds $(\exp (0.721)=2.056)-$ of marrying a college-educated spouse compared with young adults with only a high school degree, net of controls (and conditional on having transitioned to marriage). However, as in the bivariate results, young adults with bachelor's degrees were more likely to marry a college graduate than any other group. Young adults with associate's degrees had slightly higher odds of marrying a college graduate compared with those with some college, but the difference was not statistically significant.

\section{[TABLE 5 ABOUT HERE]}

Net of educational attainment, young adults with higher ASVAB scores and occupational education were more likely marry a college graduate rather than a less-educated spouse, which highlight the importance of both attractiveness and access on the marriage market. In addition, age was positively associated with spouse's education, and respondents who had a first birth prior to marriage were less likely to marry a college graduate than those without children. There were no race-ethnic differences in the likelihood of marrying a college-educated spouse at these ages.

Model 2 tests for variation among respondents with some college by institution type. In support of Hypothesis 2, young adults with some 4-year college experience, but no degree, were significantly more likely than those who only attended a 2-year college to marry a college graduate. In fact, the "some college" advantage in the previous model is reduced for 2-year attendees - while they are more likely to marry a college graduate than young adults with no college experience, the effect size is smaller and the difference is only marginally significant. By 
contrast, four-year attendees were just as likely as associate's degree holders to marry a college graduate, but still lagged behind young adults with bachelor's degrees.

Model 3 tests for variation by amount of exposure to postsecondary education. Because young adults with only a high school degree, by definition, do not have any postsecondary credits, I collapsed the high school and some college groups to test how the odds of marrying a college-educated spouse varied by the number of 2-year and 4-year credits earned, controlling for degree. Number of credits earned was not significantly associated with spouse's education, net of degree and other controls. Thus, Hypothesis 3 did not find support.

It is possible that increased exposure to higher education may be more beneficial to young adults without degrees than for college graduates. Not only are college graduates required to have some minimum number of credits (although the exact number depends on transfer/AP credits and institutional requirements), but being in school longer is not likely to yield much additional benefit for college graduates, who are already the most attractive partners on the marriage market. But for young adults without degrees, the effect of an additional semester of schooling is likely to be much more consequential for their chances of meeting college-educated partners.

\section{[TABLE 6 ABOUT HERE]}

Table 6 shows results from a model that interacts number of credits with degree earned. The coefficient for 4-year credits represents the association between credits and spouse's education for young adults with high school degrees, including "some college," while the interaction terms indicate whether the association between credits and spouse's education is significantly different for associate's and bachelor's degree-holders. The results show a positive and significant association between credits and spouse's education for young adults with high 
school degrees, but not for young adults with bachelor's degrees. The interaction term for bachelor's degree-holders is statistically significant and negative. In real terms, predicted probabilities (holding all other covariates at mean levels) indicate that the average young adults with 15 4-year college credits and no degree had a $19 \%$ chance of being married to a college graduate over a non-college graduate. That chance increases to $34 \%$ among young adults with 100 college credits but no degree. Still, young adults with bachelor's degrees who had 100 college credits still had a greater chance (48\%) of being married to a college graduate, holding all other factors equal.

I tested for gender differences in pooled models that included interactions between gender and educational attainment and number of credits. Although I expected the association between respondent's education and spouse's education to be stronger for women (Hypothesis 4), I did not find any significant differences between women and men. Results from models run separately for men and women were substantively similar to the full models presented here.

I also ran all models using a subsample restricted to respondents who were not currently enrolled in school. This helps account for potential bias in the estimates of the some college group that result from young adults either marrying before graduation or dropping out of college in order to marry. In these cases, young adults with "some college" may not be evaluated as such by potential partners. It also helps account for post-marital changes in degree attainment. However, the models with non-enrolled respondents showed the same pattern as the full models.

\section{DISCUSSION}

In this study of educational assortative mating in the years following school completion (24-31), I found that exposure to higher education was associated with a greater likelihood of marrying a 
college-educated partner, even among young adults who had some college experience but no degree. Building on previous research on marriage markets and the importance of schools for structuring social networks, I expected young adults with some college but no degree to have a better chance at crossing educational boundaries in the marriage market than their peers with no postsecondary experience, net of family background and socioeconomic status, because of the greater opportunities to meet college-educated partners that higher education affords. Consistent with Hypotheses 1 and 2, I found that young adults with some college - especially those who attended a 4-year institution - were more likely than their less educated peers to marry a college graduate. Number of college credits, which approximated the duration of postsecondary education exposure, was also positively associated with marriage to a college-educated spouse, but only for young adults who lacked a college degree (partial support for Hypothesis 3). There was no variation in these patterns by gender (no support for Hypothesis 4).

The results support the idea that schools continue to act as social intermediaries in the U.S. marriage market, despite later ages at marriage. Supply-side theories of assortative mating have long argued that institutions of higher education are an important structural source of educational homogamy in the United States. College attendance appears not only to increase one's human capital, job prospects, and overall attractiveness to potential partners on the marriage market - it also provides opportunities to form friendships and cultivate more highly educated social networks, which improve the pool of partners from which to choose a spouse. Schools are by no means the only structural source of educational homophily at these ages work and occupations appear to act in the similar manner as schools (McClendon et al., 2014), and neighborhood segregation by education and income may also play a role shaping opportunities to cross educational boundaries in marriage (Massey, Rothwell, \& Domina, 2009). 
But the results support the notion that friendships and networks formed through school have a long and underappreciated reach in mate selection that extends beyond graduation, making schools a relevant structural factor in educational assortative mating later in young adulthood.

Another key finding is that young adults with bachelor's degree maintain an advantage in the marriage market over everyone else even after accounting for time spent in college (credits earned), as well as family background, prior skills, and multiple indicators of socioeconomic status, including occupational education. This highlights the importance of a college degree in the marriage selection process - either as an indicator of a potential partner's long-term financial prospects, cultural compatibility, or both. But, again, partner preferences do not appear to be so rigid, or the educational boundaries on the marriage market so impermeable, that the opportunities to meet highly educated partners through school-related social networks are irrelevant. Even in the age of internet dating, access through more traditional networks appears to be important for partner selection. Together, the findings underline the importance of attending to macrostructural conditions, like schools and other social settings that stratify opportunities to meet partners, to understand the growing education gap in family formation, structure, and stability (Cherlin, 2010).

There are several important limitations to the current study. First, because the NLSY-97 cohort is still young, this analysis describes relatively early marriage among today's young adults (Census, 2011). Thus, the findings may not be generalizable to marriage-market dynamics later in the life course. Second, while I controlled for a variety of characteristics associated with college enrollment, degree completion, and partner choice, including social class background, high school performance and skills, and current socioeconomic status, there may be other unobservable characteristics of respondents, incidental to opportunities to meet, that explain both 
educational attainment and partner's education. Third, my models could overestimate the marriage-market benefits of college enrollment if many respondents with some college at marriage go on to complete their degrees. I tried to account for this possibility by estimating models on a sample restricted to years when respondents were not enrolled in school. In addition, any degrees earned after marriage by some respondents was likely offset by post-marital degrees earned by other respondents' partners.

In closing, the results also have implications for thinking about future educational assortative mating patterns in the United States and the role of schools. College has always been about more than improving one's human capital and labor market position - generations of students, especially young women, have been encouraged to attend college for the marriagemarket opportunities it affords (Patton, 2013; Scott, 1965). The current analysis confirms the intuition that college improves one's pool of potential partners, but also finds that young adults who do not earn degrees benefit from attending. This suggests that as postsecondary educational trajectories become more diverse, so, too, may patterns of assortative mating. If current trends continue and the share of young adults with "some college" continues to grow, we could see declines in educational homogamy among college graduates as schools allow more people the opportunity to cross educational boundaries on the marriage market. 


\section{REFERENCES}

Addo, F. R. (2014). Debt, Cohabitation, and Marriage in Young Adulthood. Demography, 51(5), 1677-1701. http://doi.org/10.1007/s13524-014-0333-6

Allison, P. (2009). Missing data. In R. E. Millsap \& A. Maydeu-Olivares (Eds.), The SAGE handbook of quantitative methods in psychology (pp. 72-89). Thousand Oaks, CA: Sage Publications.

Arum, R., Roksa, J., \& Budig, M. J. (2008). The romance of college attendance: Higher education stratification and mate selection. Research in Social Stratification and Mobility, 26(2), 107-121. http://doi.org/10.1016/j.rssm.2008.02.003

Autor, D. H., \& Dorn, D. (2013). The growth of low-skill service jobs and the polarization of the US Labor Market. American Economic Review, 103(5), 1553-1597. http://doi.org/10.1257/aer.103.5.1553

Berk, R. A. (1983). an Introduction To Sample Selection Bias in Sociological Data. American Sociological Review. http://doi.org/10.2307/2095230

Blau, P. M. (1994). Structural Contexts of Opportunities. Chicago, IL: University of Chicago Press.

Blossfeld, H.-P. (2009). Educational Assortative Marriage in Comparative Perspective. Annual Review of Sociology, 35(1), 513-530. http://doi.org/10.1146/annurev-soc-070308-115913

Bozick, R., \& Estacion, A. (2014). Do student loans delay marriage? Debt repayment and family formation in young adulthood. Demographic Research, 30(1), 1865-1891. http://doi.org/10.4054/DemRes.2014.30.69

Buss, D. M., Shackelford, T. K., Kirkpatrick, L. A., \& Larsen, R. J. (2001). A half century of mate preferences: The cultural evolution of values. Journal of Marriage and Family, 63(2), 
491-503. http://doi.org/10.1111/j.1741-3737.2001.00491.x

Census, U. S. B. of the. (2011). Estimated median age at first marriage, by sex: 1890 to the present. In Families and living arrangements: Marital status.

Cherlin, A. J. (2010). Demographic trends in the United States: A review of research in the 2000s. Journal of Marriage and Family. http://doi.org/10.1111/j.1741-3737.2010.00710.x

Christine, R. S., Robert, D. M., Schwartz, C. R., \& Mare, R. D. (2005). Trends in Educational Assortative Marriage from 1940 to 2003. Demography, 42(4), 621-646. http://doi.org/10.1353/dem.2005.0036

DiMaggio, P., \& Mohr, J. (1985). Cultural Capital, Educational Attainment, and Marital Selection. American Journal of Sociology, 90(6), 1231. http://doi.org/10.1086/228209

Feld, S. L. (1981). The Focused Organization of Social Ties. American Journal of Sociology, 86(5), 1015. http://doi.org/10.1086/227352

Fernández, R., Guner, N., \& Knowles, J. (2005). Love and Money : A Theoretical and Empirical Analysis of Household Sorting and Inequality. The Quarterly Journal of Economics, 120(1), 273-344. http://doi.org/10.2307/25098737

Frank, K. A., Muller, C., \& Mueller, A. S. (2013). The Embeddedness of Adolescent Friendship Nominations: The Formation of Social Capital in Emergent Network Structures. American Journal of Sociology, 119(1), 216-253. http://doi.org/10.1086/672081

Heckman, J. (1979). Sample Selection Bias as a Specification Error Author ( s ): James J . Heckman Published by : The Econometric Society Stable URL : http://www.jstor.org/stable/1912352. Econometrica, 47(1), 153-161. http://doi.org/10.3982/ECTA8640

Hout, M. (2012). Social and Economic Returns to College Education in the United States. 
Annual Review of Sociology, 38, 379-400.

http://doi.org/10.1146/annurev.soc.012809.102503

Kalmijn, M. (1998). Intermarriage and Homogamy: Causes, Patterns, Trends. Annual Review of Sociology, 24(1), 395-421. http://doi.org/10.1146/annurev.soc.24.1.395

Kalmijn, M., \& Flap, H. (2001). Assortative Meeting and Mating: Unintended Consequences of Organized Settings for Partner Choices. Social Forces, 79(4), 1289-1312. http://doi.org/10.1353/sof.2001.0044

Laumann, E. O., Ellingson, S., Mahay, J., Paik, A., \& Youm, Y. (2004). The sexual organization of the city. Chicago, IL: University of Chicago Press.

Mare, R. D. (1991). Five Decades of Educational Assortative Mating. American Sociological Review, 56(1), 15-32. http://doi.org/10.2307/2095670

Massey, D. S., Rothwell, J., \& Domina, T. (2009). The Changing Bases of Segregation in the United States. The ANNALS of the American Academy of Political and Social Science, 626(November 2009), 74-90. http://doi.org/10.1177/0002716209343558

McClendon, D., Kuo, J. C. L., \& Raley, R. K. (2014). Opportunities to Meet: Occupational Education and Marriage Formation in Young Adulthood. Demography, 51(4), 1319-1344.

McPherson, M., Smith-lovin, L., \& Cook, J. M. (2001). Birds of a Feather : Homophily in Social Networks. Annual Review of Sociology, 27, 415-444. http://doi.org/10.1146/annurev.soc.27.1.415

Musick, K., Brand, J. E., \& Davis, D. (2012). Variation in the relationship between education and marriage: Marriage market mismatch? Journal of Marriage and Family, 74(1), 53-69. http://doi.org/10.1111/j.1741-3737.2011.00879.x

Oppenheimer, V. K. (1988). A Theory of Marriage Timing. American Journal of Sociology, 
94(3), 563-591.

Patton, S. (2013, March 29). Letter to the Editor: Advice for the young women of Princeton: the daughters I never had. The Daily Princetonian. Retrieved from http://dailyprincetonian.com/opinion/2013/03/letter-to-the-editor-advice-for-the-youngwomen-of-princeton-the-daughters-i-never-had/

Press, J. E. (2004). Cute butts and housework: A gynocentric theory of assortative mating. Journal of Marriage and Family. http://doi.org/10.1111/j.0022-2445.2004.00074.x

Raley, R. K., \& Bratter, J. (2004). Not Even if You Were the Last Person on Earth! Journal of Family Issues, 25(2), 167-181. http://doi.org/10.1177/0192513x03256515

Rosenfeld, M. J. (2008). Racial, Educational and Religious Endogamy in the United States: A Comparative Historical Perspective. Social Forces, 87(1), 1-31. http://doi.org/10.1353/sof.0.0077

Rosenfeld, M. J., \& Thomas, R. J. (2012). Searching for a Mate: The Rise of the Internet as a Social Intermediary. American Sociological Review, 77(4), 523-547. http://doi.org/10.1177/0003122412448050

Schwartz, C. R. (2013). Trends and Variation in Assortative Mating: Causes and Consequences. Annual Review of Sociology, 39(1), 451-470. http://doi.org/10.1146/annurev-soc-071312145544

Scott, J. F. (1965). THE AMERICAN COLLEGE SORORITY: ITS ROLE IN CLASS AND ETHNIC ENDOGAMY. American Sociological Review, 30(4), 514-527. http://doi.org/10.2307/2091341

South, S. J. (1991). Sociodemographic Differentials in Mate Selection Preferences. Journal of Marriage and Family, 53(4), 928. http://doi.org/10.2307/352998 
Sweeney, M. M. (2002). Two Decades of Family Change: The Shifting Economic Foundations of Marriage. Source American Sociological Review, 67(1), 132-147. http://doi.org/10.2307/3088937

Sweeney, M. M., \& Cancian, M. (2004). The changing importance of white women's economic prospects for assortative mating. Journal of Marriage and Family. http://doi.org/10.1111/j.0022-2445.2004.00073.x

Swidler, A. (2001). Talk of love: How culture matters. Chicago, IL: University of Chicago Press. Symonds, W., \& Schwartz, R. (2011). Pathways to prosperity: Meeting the challenge of preparing young Americans for the 21st century. By the Pathways to Prosperity, 1-46. Retrieved from http://www.itf.org.nz/assets/Events-and-Forums/2011-Events/ITFConference-2011/Conference-2011-presentations/KN1-William-Symonds-PDF.pdf

Thornton, A., Axinn, W. G., \& Teachman, J. D. (1995). The Influence of School Enrollment and Accumulation on Cohabitation and Marriage in Early Adulthood. American Sociological Review, 60(5), 762. http://doi.org/10.2307/2096321

White, I. R., Royston, P., \& Wood, A. M. (2011). Multiple imputation using chained equations: Issues and guidance for practice. Statistics in Medicine, 30(4), 377-399. http://doi.org/10.1002/sim.4067

Xie, Y., Raymo, J. M., Goyette, K., \& Thornton, A. (2003). Economic potential and entry into marriage and cohabitation. Demography, 40(2), 351-367. http://doi.org/10.1353/dem.2003.0019

Zajacova, A., Rogers, R. G., \& Johnson-Lawrence, V. (2012). Glitch in the gradient: Additional education does not uniformly equal better health. Social Science and Medicine, 75(11), 2007-2012. http://doi.org/10.1016/j.socscimed.2012.07.036 
Table 1. Sample characteristics (unweighted).

\begin{tabular}{lcccc}
\hline & $\begin{array}{c}\text { Full } \\
\text { NLSY97 } \\
\text { sample }\end{array}$ & $\begin{array}{c}\text { Married } \\
\text { respondents } \\
\text { sample }\end{array}$ & $\begin{array}{c}\text { Non-college- } \\
\text { educated } \\
\text { spouse }\end{array}$ & $\begin{array}{c}\text { College- } \\
\text { educated } \\
\text { spouse }\end{array}$ \\
\cline { 2 - 5 } No. of respondents, ages 24-31 & 5807 & 1469 & 877 & 592 \\
Women (\%) & $46 \%$ & $50 \%$ & $52 \%$ & $46 \%$ \\
Race-ethnicity (\%) & $47 \%$ & 63 & 55 & 74 \\
Non-Hispanic White & 30 & 18 & 23 & 11 \\
Non-Hispanic Black & 19 & 16 & 19 & 12 \\
Hispanic & 4 & 3 & 3 & 4 \\
Other race-ethnicities & & & & \\
Parental educational attainment (\%) & $13 \%$ & 9 & 13 & 4 \\
Less than high school & 32 & 29 & 36 & 19 \\
High school & 23 & 25 & 27 & 22 \\
Associate's degree & 26 & 32 & 19 & 51 \\
College or more & 5 & 4 & 4 & 4 \\
Missing & & & & \\
\hline
\end{tabular}


Table 2. Comparison of survey, transcript, and imputed educational measures in study sample (unweighted).

\begin{tabular}{lccc}
\hline & Survey & Transcript & Imputed \\
\cline { 2 - 4 } Educational attainment (\%) & & & \\
High school degree & $21 \%$ & $24 \%$ & $20 \%$ \\
Some college, no degree & 35 & 37 & 39 \\
Associate's degree & 8 & 6 & 6 \\
Bachelor's degree & 36 & 34 & 35 \\
Number of credits & & & \\
2-year credits & 12 & 9 & 10 \\
4-year credits & 48 & 43 & 47 \\
Respondents & & & \\
\hline
\end{tabular}


Table 3. Selected time-varying characteristics before and after imputation (unweighted).

\begin{tabular}{lcc}
\hline & Pre-imputed & Imputed \\
\hline Family income, 1997 (logged) & 10.6 & 10.5 \\
\% Missing & 25 & \\
& & \\
Annual earnings (logged) & 9.1 & 9.0 \\
\% Missing & 15 & \\
& & 16 \\
Currently enrolled in school (0/1) & 16 & \\
\% Missing & 0 & \\
& & 11 \\
Employment status & & 24 \\
Unemployed & 10 & 65 \\
Part-time & 24 & \\
Full-time & 65 & 50 \\
Missing & 1 & \\
& & \\
College-Prep Math (0/1) & 50 & \\
\% Missing & 0 & \\
High school GPA & & \\
\% Missing & 3.0 & \\
ASVAB score & 23 & \\
\% Missing & 55.9 & \\
\hline
\end{tabular}


Table 4. Share of married respondents married to a college-educated spouse, by respondent's educational attainment, ages 24-31 (weighted).

\begin{tabular}{lc}
\hline & $\begin{array}{c}\text { \% Married to a college } \\
\text { graduate }\end{array}$ \\
\cline { 2 - 2 } High school, no postsecondary & $13 \%$ \\
Some college, no degree & 29 \\
2-year school only & 25 \\
Some 4-year school & 39 \\
Associate's degree & 49 \\
Bachelor's degree & 68 \\
\hline
\end{tabular}


Table 5. Coefficients from logistic regression models predicting spouse's educational attainment (college-educated vs. non-college-educated), ages 24-31, weighted.

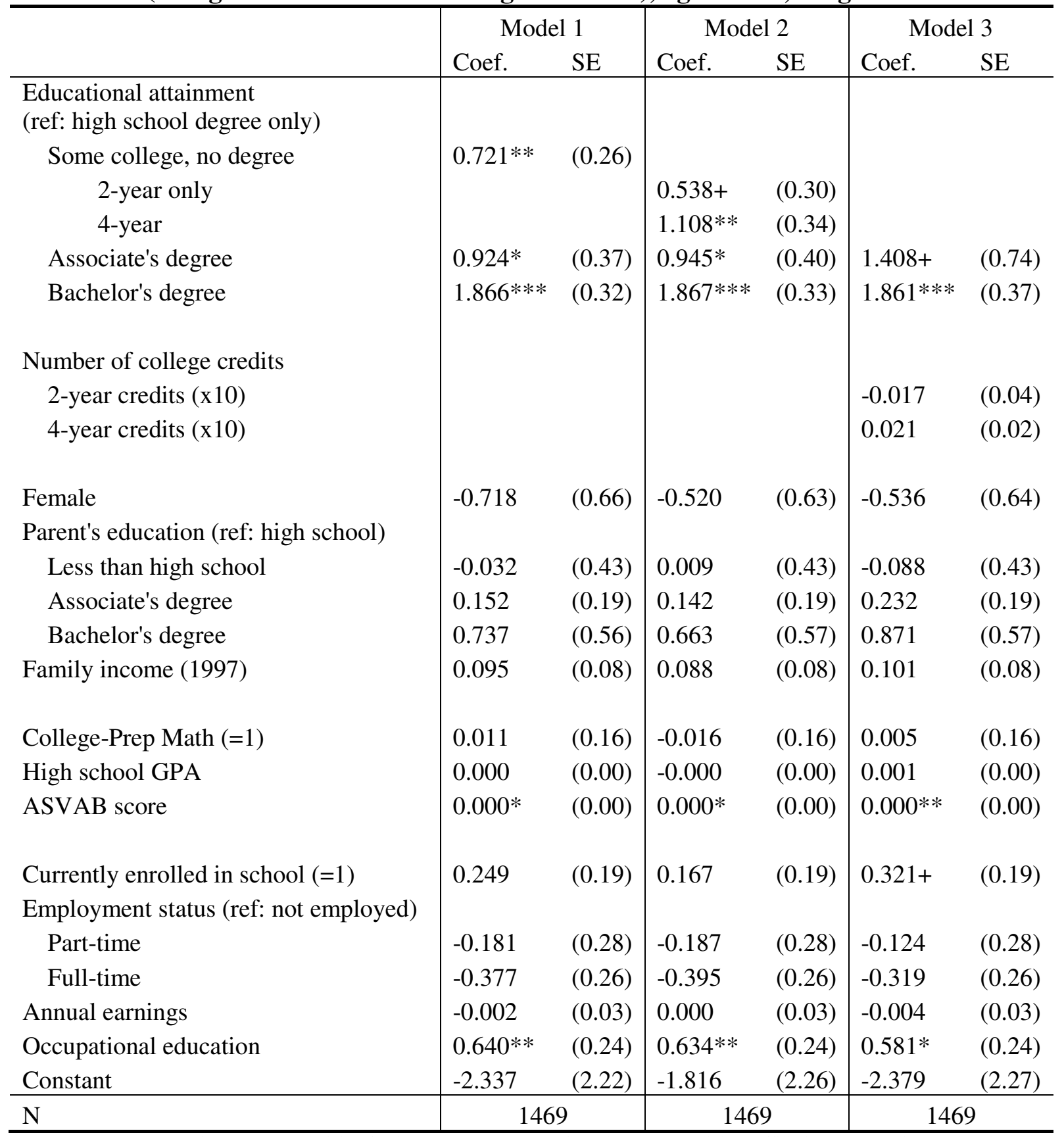

Note: All models control for age, race-ethnicity, family structure at age 12, first birth status, religious affiliation, metropolitan and regional residence, and a selection correction hazard.

$\dagger \mathrm{p}<0.1 * \mathrm{p}<0.05 * * \mathrm{p}<0.01 * * * \mathrm{p}<0.001$ 
Table 6. Interaction between number of college credits and degree. Coefficients from logistic regression models predicting spouse's educational attainment (college-educated vs. non-college-educated), ages 24-31, weighted.

\begin{tabular}{|c|c|c|}
\hline & Coef. & SE \\
\hline \multicolumn{3}{|l|}{ Educational Attainment (High school) } \\
\hline Associate's degree & 0.040 & $(0.05)$ \\
\hline Bachelor's degree & $0.093 * *$ & $(0.03)$ \\
\hline \multicolumn{3}{|l|}{ Number of college credits } \\
\hline 2-year credits & 0.035 & $(0.06)$ \\
\hline 4-year credits & $0.094 * *$ & $(0.03)$ \\
\hline \multicolumn{3}{|l|}{ Interactions } \\
\hline Associate's * 2-year credits & -0.163 & $(0.11)$ \\
\hline Associate's * 4-year credits & -0.137 & $(0.10)$ \\
\hline Bachelor's * 2-year credits & $-0.179+$ & $(0.11)$ \\
\hline Bachelor's * 4-year credits & $-0.116 * *$ & $(0.04)$ \\
\hline Constant & -1.917 & $(2.27)$ \\
\hline $\mathrm{N}$ & \multicolumn{2}{|c|}{1469} \\
\hline
\end{tabular}

